\title{
THE GENDER WAGE GAP IN TURKEY ${ }^{[*]}$
}

\author{
Arda AKTAŞ $\left.{ }^{[*}\right]$ \\ Gökçe UYSAL ${ }^{[* *]}$
}

\begin{abstract}
The most prominent form of gender discrimination in the labor market is the gender gap in wages. Using the Wage Structure Survey, a firm-level data set, we study the gender wage gap in Turkey. We concentrate on formal employment as this is the jurisdiction of the Labor Code in Turkey. Although women earn 3\% less than men on average, a wider look reveals important differences along the entire wage distribution. There is virtually no gender gap at the lower end of the wage distribution. More surprisingly, women seem to earn about 5 percent more than men at the top. Using quantile regressions which allow the study of the gender gap along the entire wage distribution, we find that women actually earn 8 percent less at the median. Moreover, at the high end of the wage distribution women earn 4.5 percent less than men once we control for differences in basic labor market characteristics such as education and labor market experience. The decomposition results reveal the unexplained part of the gender wage gap is actually larger than that observed in raw data.
\end{abstract}

Keywords: Gender wage gap, Quantile Regression, Machado-Mata Decomposition

JEL Classification: J16, J31, J71

\section{TÜRKIYYE'DE CİNSIYYETE DAYALI ÜCRET FARKLILIKLARI}

\section{Özet}

İşgücü piyasalarında toplumsal cinsiyet ayrımcılığının en çok öne çıkan şekillerinden biri kadın erkek ücretleri arasındaki farklılıklardır. Bu makalede firma bazında toplanan Kazanç Yapısı Anketi verilerini kullanılarak kadın erkek ücret farklılıkları incelenmektedir. İş Kanunu'nun yetki alanı olan kayıtlı istihdama odaklanılmaktadır. Ortalamada kadınlar erkeklerden yüzde 3 daha az kazanıyor olmalarına rağmen bütün ücret dağılımına bakıldığında önemli farklılıklar göze çarpmaktadır. Ücret dağılımının alt kısmında kadın erkek ücretleri arasında neredeyse fark bulunmamaktadır. Daha şaşırtıcı bir şekilde

[*] We are grateful to Seyfettin Gursel, Zumrut Imamoglu and Duygu Guner for valuable comments. We thank participants at the MEEA 2010 and International Conference on Economics by the Turkish Economic Association 2010. All errors are our own.

${ }^{[* *}$ State University of New York at Stony Brook, Economics Department Stony Brook University Stony Brook, NY 11794-4384 Tel: +1 6316327540 Fax: +1 6316327516 aktas.arda@stonybrook.edu

[***] Bahcesehir University Center for Economic and Social Research (Betam), Osmanpaşa Mektebi Sok. No. 4-6 Beşiktaş İstanbul Tel: +902123810498 Fax: +902123810450 gokce.uysal@eas.bau.edu.tr 
ücret dağılımının üst kısmında kadınlar erkeklerden yaklaşık yüzde 5 daha fazla ücret kazanıyor gibi durmaktadır. Kantil regresyon yöntemleri kullanılarak tüm ücret dağılımı üzerine yapılan analizde kadınların ortanca ücretlerde erkeklerden yüzde 8 daha az kazandığı ortaya konmaktadır. Ayrıca kadınlarla erkekler arasında eğitim, işgücü piyasası tecrübesi gibi özelliklerden kaynaklanan farklılıklar dikkate alındığında ücret dağılımının üst kısmında da kadınların erkeklerden yüzde 4,5 daha az ücret aldıkları görülmektedir. Ayrıștırma analizleri işgücü piyasası getirilerinden kaynaklanan kadın erkek ücret farklılığının açıklanamayan kısmının aslında gözlemlenenden derin olduğuna işaret etmektedir.

Anahtar Kelimeler: Kadın erkek ücret farklılıkları, kantil regresyon, Machado-Mata ayrıştırması

JEL Sınıflaması: J16, J31, J71

\section{Introduction}

The gender wage gaps have been elaborately studied in many countries around the world to reveal gender discrimination in labor markets. Earlier studies on the gender gap in wages focus on the differences in mean wages. More recent research has concentrated on studying the gender wage gap along the entire wage distribution to reveal important patterns. In most countries women earn less than men at the top of the distribution. Researchers have attributed this finding to glass ceilings women face. Technically, glass ceilings exist when the gender wage gap at the $90^{\text {th }}$ percentile exceeds the reference gap by at least 2 percentage points. At the other end of the distribution, the gender gap widens in many countries as well, pointing to sticky floors. A sticky floor effect exists when the $10^{\text {th }}$ percentile gender wage gap exceeds the reference gap by at least 2 points. Following this strand, we study the gender gap along the wage distribution in Turkey to analyze the existence of sticky floors and glass ceilings.

Figure I: Raw gender gap by quintile

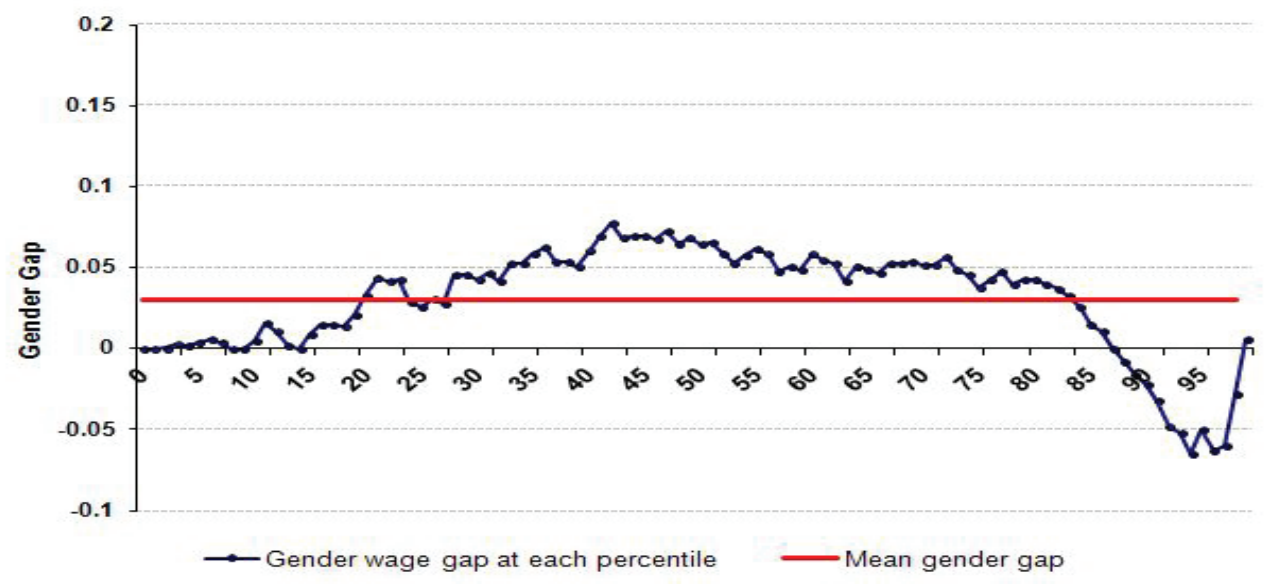

Source: Wage Structure Survey, 2006 
The labor market in Turkey has a dual structure, i.e. there is a formal and an informal labor market. In the formal labor market, social security taxes are paid, the minimum wage is binding and the labor code dictates "equal pay for equal work". In the informal labor market, the employees are not registered at the Social Security Institution and the employers are not bound by the labor code. We choose to focus on the formal labor market in Turkey to study the gender wage gap given that "equal pay for equal work" should be binding in this segment of the labor market and try to analyze whether a gender wage gap persists in spite of this legal regulation. We use data from the 2006 Wage Structure Survey, collected at the firm level by TURKSTAT.

At about 3 percent, there is a small but significant gender wage gap in the formal labor market in Turkey. However, gender differences in wages are not uniform across the wage distribution. Figure 1 plots the gender wage gap at different percentiles. The gender wage gap seems to fluctuate around zero at the very low end of the distribution. In other words, sticky floor effects are not observed in the raw data in Turkey. The gap increases to about 6.47 percent at the median. Surprisingly, we observe a sharp decrease in the gender gap at the top of the wage distribution. It even changes sign around the $90^{\text {th }}$ percentile. To clarify, the gender gap becomes negative 6.49 percent at the $94^{\text {th }}$ percentile. That is, the data indicates that men may actually be earning lower wages than women at the very top of the wage distribution.

Why does the gender gap vary so drastically along the wage distribution? The usual explanations may apply. We know that men and women in the labor market have different characteristics that may underlie the gender wage gap, such as education, labor market experience, tenure. We also know that labor market returns to these characteristics may differ. In other words, the labor market may not treat these characteristics equally across genders. Lastly, both the characteristics and the returns may change along the wage distribution. Furthermore, the extent to which characteristics and returns change may depend on gender.

We conduct the analysis in three steps. First, we run quantile regressions along the wage distribution, assuming that the labor market returns do not vary by gender. We find that the differences in characteristics between men and women hide a larger gender gap in wages. Even under the assumption that the labor market returns are the same, when we control for basic characteristics such as education and age, the gender wage gap becomes wider all throughout the distribution. At the median, women earn less than 8 percent of what men earn when we control for basic labor market characteristics such as education and labor market experience. The most striking effect occurs at the top end. Contrary to what the raw data indicates, i.e. that men earn about 5 percent less than women, we find that women's wages are about 4.5 percent below those of men above the $90^{\text {th }}$ percentile once differences in characteristics are included in the estimations.

Secondly, we run separate regressions for males and females, allowing labor market returns to differ by gender. We find that the coefficients in the Mincerian regressions of males and females are statistically different. Returns to age and education are generally higher for females than for males. More importantly, the gender differences in coefficients increase as we move up the wage distribution. 
As a last step, we use the Machado-Mata technique to quantify the contributions of differences in characteristics and differences in returns to the overall gender gap. Machado-Mata decomposition results indicate that the unexplained components exceed the gender wage gap.

\section{Literature Survey}

The earlier literature that studies the gender wage gap consists of least squares regressions and Blinder ${ }^{1}$ - Oaxaca ${ }^{2}$ decompositions. These methods concentrate on the mean of the wage distribution, hence provide a limited understanding of the gender gap. Therefore, several other methods have been developed to study the gender gap along the entire wage distribution and important differences in gender gaps along the wage distribution were revealed.

Albrect ${ }^{3}$ are one of the first to study the gender gap along the wage distribution and they use quantile regression and Machado and Mata ${ }^{4}$ decomposition techniques. The authors find that the gender wage gap is much wider at the top of the distribution when they control for covariates such as age and education. They also find that the unexplained part of the gender wage gap is considerably large. Following their work, Arulampalam ${ }^{5}$ study the gender wage gap for 11 countries in Europe using the quantile regression techniques to study the gender wage gap along the wage distribution as well as the Machado-Mata decomposition technique. They find that glass ceilings and sticky floors exist in many countries. The authors also show the differences in wages due to differences in returns are sizeable and sometimes even larger than the observed gender gap itself. Christofides et al. ${ }^{6}$ confirm these findings using data from 27 European countries.

Gender gap in wages has also been studied in Turkey. However, all the studies on Turkey concentrate on the mean gender gap and its decomposition. Ours is the first study that studies the gender wage gap along the entire wage distribution to reveal important differences in gender wage gaps along the wage distribution.

Dayioglu and Kasnakoğlu ${ }^{7}$ focus on urban wage earners using the Household Income and Expenditure Survey of 1987 and find a gender wage gap of 4 percent. The authors show that at

1 Blinder, Alan, "Wage Discrimination: Reduced Form and Structural Estimates", Journal of Human Resources, 8 (4), 436-455,1973.

2 Oaxaca, Ronald, "Male-Female Wage Differentials in Urban Labor Markets". International Economic Review, 14(3), 693-709, 1973.

3 Albrecht, James and Bjorklund, Anders and Vroman, Susan, “Is There a Glass Ceiling in Sweden?” Journal of Labor Economics, 21 (1), 2003, 145-77.

4 Machado, José A. F. and Mata, José, "Counterfactual Decomposition of Changes in Wage Distributions using Quantile Regression”, Journal of Applied Econometrics, 20(4), 445-465, 2005.

5 Arulampalam, Wiji and L. Booth, Alison and Bryan, Mark L. "Is There a Glass Ceiling over Europe? Exploring the Gender Pay Gap across the Wage Distribution” Industrial and Labor Relations Review, 60(2), 163-186, October 2004.

6 Christofides, Louis N., and Polycarpou, Alexandros, and Vrachimis, Konstantinos, "Gender Wage Gaps, 'Sticky Floors' and 'Glass Ceilings' in Europe”, Labour Economics, 21, 86-102, 2013.

7 Dayığlu, Meltem. and Kasnakoğlu, Zehra, "Kentsel Kesimde Kadın ve Erkeklerin Işgücüne Katılımları ve Kazanç Farklılıkları”, Metu Studies in Development, 24(3), 329-361, 1997. 
least two thirds of the gender gap is due to discrimination. Gender gap based on data from the Household Labor Force Survey of 1988 is 2 percent according to Dayioglu and Tunali ${ }^{8}$. The same study also uses the Household Labor Force Survey of 1994 and finds a gender wage gap of 15 percent. Further analysis shows that at least half of the gender gap is due to discrimination. Again for 1994, Tansel ${ }^{9}$ uses yet another data set, i.e. Household Expenditure Survey, and compute a gender wage gap of 27 percent for the formal and informal wage earners as well as for the self-employed. Tansel ${ }^{10}$ concludes that 37 percent of the gender gap can be attributed to discrimination.

Using the Employment and Wage Structure Survey of 1994, Ilkkaracan and Selim ${ }^{11}$ find a gender gap of 35 percent. The authors point out that this may overestimate the gender gap in the labor market, given that their sample consists of firm-level data from manufacturing, electricity, gas and water, mining and quarrying sectors. The discrimination component can increase up to 42 percent depending on the controls used.

The closest study to ours is Cudeville and Gurbuzer ${ }^{12}$. They emphasize that the gender gap is not uniform across the wage distribution; however, they restrict their analysis to the mean gender wage gap using a Blinder (1973) - Oaxaca (1973) decomposition.

Ours is the first study on the labor market in Turkey that studies the gender gap along the wage distribution using the quantile regression methodology coupled with the Machado-Mata decomposition. Bodur and Tansel ${ }^{13}$ also use the quantile regression techniques, however, they analyze the evolution of wage inequality in Turkey from 1994 to 2002.

\section{Data and Descriptive Statistics}

The data used for the analysis in this paper comes from the Wage Structure Survey conducted by TURKSTAT. Wage Structure Survey is a firm-level data set which provides detailed information on workers' wages, workers' demographic characteristics as well as firm characteristics. Since the data is collected at the firm level, it consists only of formally employed workers. As explained above, the Labor Code and hence the clause against gender discrimination is binding only for formal labor contracts. Hence, we choose to focus on formal employment and use the 2006

8 Dayığlu, Meltem, and Tunalı, Insan, "Falling behind While Catching up: Changes in the Female-Male Wage Differential in Urban Turkey 1988 to 1994", Unpublished manuscript, 2003.

9 Tansel, Aysit, "Wage Earners, Self Employed and Gender in the Informal Sector in Turkey", Economic Research Forum Working Papers 0102, 2003.

10 Tansel, Ibid.

11 Ilkkaracan, İpek and Selim, Raziye, “The Gender Wage Gap in the Turkish Labor Market”, Review of Labour Economics and Industrial Relations, 21(2), 563-59, 2007

12 Cudeville, Elisabeth and Gurbuzer, Leman Yonca, "Gender Wage Discrimination in the Turkish Labor Market: Can Turkey Be Part of Europe?”, Comparative Economic Studies, 52(3), 429-463, September 2010.

13 Tansel, Aysit, and Fatma Bircan Bodur, "Wage inequality and returns to education in Turkey: A quantile regression analysis", Review of Development Economics, 16(1) (2012): 107-121. 
Wage Structure Survey. It is the largest data set available on employment and also contains detailed industry and occupation information as well as information on administrative posts and collective bargaining. We restrict our analysis to employees working full time, who constitute 99.3 percent of the entire sample. The wages are taken as earnings in November 2006 YTL. In Turkey, a majority of the workers are paid on a monthly basis. So, the dependent variable is the logarithm of gross monthly wage. The wages are measured in November 2006 YTL $^{14}$.

Table I: Descriptive statistics

\begin{tabular}{|c|c|c|}
\hline & Male & Female \\
\hline $\mathrm{Nb}$ of observations & 141,767 & 40,298 \\
\hline Wages & 1351 & 1347 \\
\hline Log wages & 6.95 & 6.92 \\
\hline \multicolumn{3}{|l|}{ Basic Control Variables } \\
\hline Age (years) & 34.29 & 30.94 \\
\hline Experience(years) & 17.64 & 12.64 \\
\hline \multirow[t]{2}{*}{ Tenure(years) } & 5.22 & 4.04 \\
\hline & Male (\%) & Female (\%) \\
\hline \multicolumn{3}{|l|}{ Educational attainment } \\
\hline Elementary education & 43.96 & 25.17 \\
\hline High school & 20.81 & 26.86 \\
\hline Vocational high school & 14.44 & 9.91 \\
\hline University or higher & 20.78 & 38.07 \\
\hline Total & 100 & 100 \\
\hline \multicolumn{3}{|l|}{ Firm size } \\
\hline $10-49$ & 27.92 & 29.31 \\
\hline $50-249$ & 26.96 & 30.03 \\
\hline $250+$ & 45.12 & 40.66 \\
\hline Total & 100 & 100 \\
\hline \multicolumn{3}{|l|}{ Administrative post } \\
\hline No & 82.21 & 83.85 \\
\hline Yes & 17.79 & 16.15 \\
\hline Total & 100 & 100 \\
\hline \multicolumn{3}{|l|}{ Collective bargaining } \\
\hline No & 77.92 & 88.66 \\
\hline Yes & 22.08 & 11.34 \\
\hline Total & 100 & 100 \\
\hline \multicolumn{3}{|l|}{ Industry } \\
\hline C Mining and quarrying & 2.45 & 0.4 \\
\hline DA Manufacture of food products, beverages and tobacco products & 5.11 & 2.96 \\
\hline DB Manufacture of textiles and textile products & 12.01 & 20.29 \\
\hline DC Manufacture of leather and leather products & 0.82 & 0.59 \\
\hline DD Manufacture of wood and wood products & 0.53 & 0.17 \\
\hline
\end{tabular}

14 Approximately one third of the employees in our data set seem to be employed at the minimum wage, which was $531 \mathrm{TL}$ in 2006. The data from the Household Labor Force Surveys indicates that only 17.3 percent of the employed who work full time formally for firms with at least 10 employees in 2006 earn between 500 TL and 600 TL per month. This implies that firms underreport wages to pay lower taxes. Unfortunately, there is no econometric method that corrects for underreporting nor a way of correctly identifying minimum wage vs. underreported wage. So we exclude this group from the wage regressions. 


\begin{tabular}{|c|c|c|}
\hline DE Manufacture of pulp, paper and paper products; publishing and printing & 1.85 & 1.24 \\
\hline DF Manufacture of coke, refined petroleum products and nuclear fuel & 0.46 & 0.28 \\
\hline DG Manufacture of chemicals, chemical products and man-made fibers & 2.53 & 2.29 \\
\hline DH Manufacture of rubber and plastic products & 1.93 & 0.88 \\
\hline DI Manufacture of other non-metallic mineral products & 3.84 & 1.75 \\
\hline DJ Manufacture of basic metals and fabricated metal products & 7.78 & 2.03 \\
\hline DK Manufacture of machinery and equipment n.e.c. & 4.67 & 1.99 \\
\hline DL Manufacture of electrical and optical equipment & 2.72 & 3.24 \\
\hline DM Manufacture of transport equipment & 4.43 & 1.2 \\
\hline DN Manufacturing n.e.c. & 1.67 & 1.66 \\
\hline E Electricity, gas and water supply & 2.54 & 0.75 \\
\hline F Construction & 4.87 & 2.2 \\
\hline G Wholesale and retail trade; repair of motor vehicles and motorcycles & 13.91 & 17.02 \\
\hline H Hotels and restaurants & 3.65 & 3.48 \\
\hline I Transport, storage and communication & 9.53 & 8.79 \\
\hline J Financial intermediation & 1.92 & 5.32 \\
\hline K Real estate, renting and business activities & 5.65 & 6.75 \\
\hline M Education & 2.03 & 6.71 \\
\hline N Health and social work & 1.33 & 6.42 \\
\hline O Other community, social and personal service activities & 1.76 & 1.59 \\
\hline Total & 100 & 100 \\
\hline \multicolumn{3}{|l|}{ Occupation (ISCO 2 digits) } \\
\hline 11 Legislators and Senior Officials & 0.02 & 0.01 \\
\hline 12 Corporate Managers & 5.77 & 5.58 \\
\hline 13 General Managers & 0.5 & 0.37 \\
\hline 21 Physical, Mathematical and Engineering Science Professionals & 2.93 & 2.67 \\
\hline 22 Life Science and Health Professionals & 0.54 & 1.73 \\
\hline 23 Teaching Professionals & 1.04 & 4.9 \\
\hline 24 Other Professionals & 2.27 & 5.94 \\
\hline 31 Physical and Engineering Science Associate Professionals & 6.65 & 4.82 \\
\hline 32 Life Science and Health Associate Professionals & 0.62 & 2.81 \\
\hline 33 Teaching Associate Professionals & 0.04 & 0.21 \\
\hline 34 Other Associate Professionals & 9.21 & 14.84 \\
\hline 41 Office Clerks & 7.33 & 14.4 \\
\hline 42 Customer Services Clerks & 1.61 & 6.17 \\
\hline 51 Personal and Protective Services Workers & 5.82 & 3.15 \\
\hline 52 Models, Salespersons and Demonstrators & 2.84 & 4.26 \\
\hline 61 Market-Oriented Skilled Agricultural and Fishery Workers & 0.36 & 0.09 \\
\hline 71 Extraction Building Trades Workers & 4.42 & 0.39 \\
\hline 72 Metal, Machinery and Related Trades Workers & 8.9 & 1.94 \\
\hline 73 Precision, Handicraft, Printing and Related Trades Workers & 2.24 & 1.39 \\
\hline 74 Other Craft and Related Trades Workers & 6.53 & 8.14 \\
\hline 81 Stationary-Plant and Related Operators & 2.75 & 0.5 \\
\hline 82 Machine Operators and Assemblers & 8.97 & 6.2 \\
\hline 83 Drivers and Mobile-Plant Operators & 5.16 & \\
\hline 91 Sales and Services Elementary Occupations & 4.94 & 5.22 \\
\hline 92 Agricultural, Fishery and Related Laborers & 0.07 & 0.04 \\
\hline 93 Laborers in Mining, Construction, Manufacturing and Transport & 8.48 & 4.24 \\
\hline Total & 100 & 100 \\
\hline
\end{tabular}


Descriptive statistics of our sample are provided in Table 1. Note that there are stark differences in characteristics across genders. Females are younger and therefore have lower levels of potential job market experience and tenure. However, females in employment have much higher education levels compared to males: 38.07 percent of females have at least a college degree whereas only 20.78 percent of males do ${ }^{152} .26 .86$ percent of females are general high school graduates compared to 20.81 percent of males. Vocational school graduates constitute 9.91 percent of females and 14.44 percent of males in our sample. There are similar albeit less pronounced differences in other control variables. Females tend to work for smaller firms. Moreover, they are less likely to be covered by collective bargaining agreements and less likely to hold administrative posts.

Raw data indicates that the gender gap is 3 percent. To get a clear idea of differences along the wage distribution, Figure 2 presents the gender gaps at each percentile. First, concentrate on the graph on the upper left hand side, which is the same as Figure 1. The gender wage gap starts around zero at the lower tail, and stays there for the lowest quintile, after which it starts decreasing slowly. It reaches its peak of 7.74 percent at the $42^{\text {nd }}$ percentile and decreases very slowly until the upper tail of the distribution. From the $85^{\text {th }}$ percentile on, we observe a steeper descent in the gender gap, and it even turns positive after the $90^{\text {th }}$ percentile. In other words, it seems like men earn less than women at the top of the wage distribution.

Remember women in our sample are more educated than men. In other words, women are much more likely to be college graduates, especially at the top end of the wage distribution. Therefore, they may have higher wages just because the returns to college are higher than the returns to high school. To see whether this may be the case, we plot the gender gap at all percentiles by education levels in Figure 2.Let us concentrate on the gender gap for college graduates. Observe that it is almost zero at the lower end of the distribution, up to the $5^{\text {th }}$ percentile. However, it starts increasing consistently as we move up the distribution. Having reached 20 percent around the median, it stagnates at that level until the $70^{\text {th }}$ percentile after which it increases slightly again. Even though there is a minor decrease around the $85^{\text {th }}$ percentile, the gender gap barely goes below 20 percent, it even surpasses 20 percent after the $90^{\text {th }}$ percentile. Clearly, a gender gap exists for the college graduates, is sizeable and persistently increasing along the wage distribution. The gender gap for high school graduates exhibits a similar pattern along the wage distribution, except for the fact that towards the upper tail, the gender gap decreases considerably. A strikingly pronounced figure emerges for the elementary school graduates. The gender gap increases fast as we move up the wage distribution. It reaches 50 percent around the $90^{\text {th }}$ percentile, and then it drops sharply.

As pointed out above, the raw gender gap indicates that men may be earning less than women. However, Figure 2 provides evidence that women may be more educated than men at the top of the wage distribution and hence enjoy higher wages. In other words, when we control for

$15 \quad{ }^{2}$ Low LFPR of women in Turkey coupled with high LFPR for college graduates imply that the females in employment are much better educated than their male counterparts. 
education (and other characteristics), the gender wage gap may possibly change signs along the wage distribution.

Figure 2: Gender wage gaps by education level
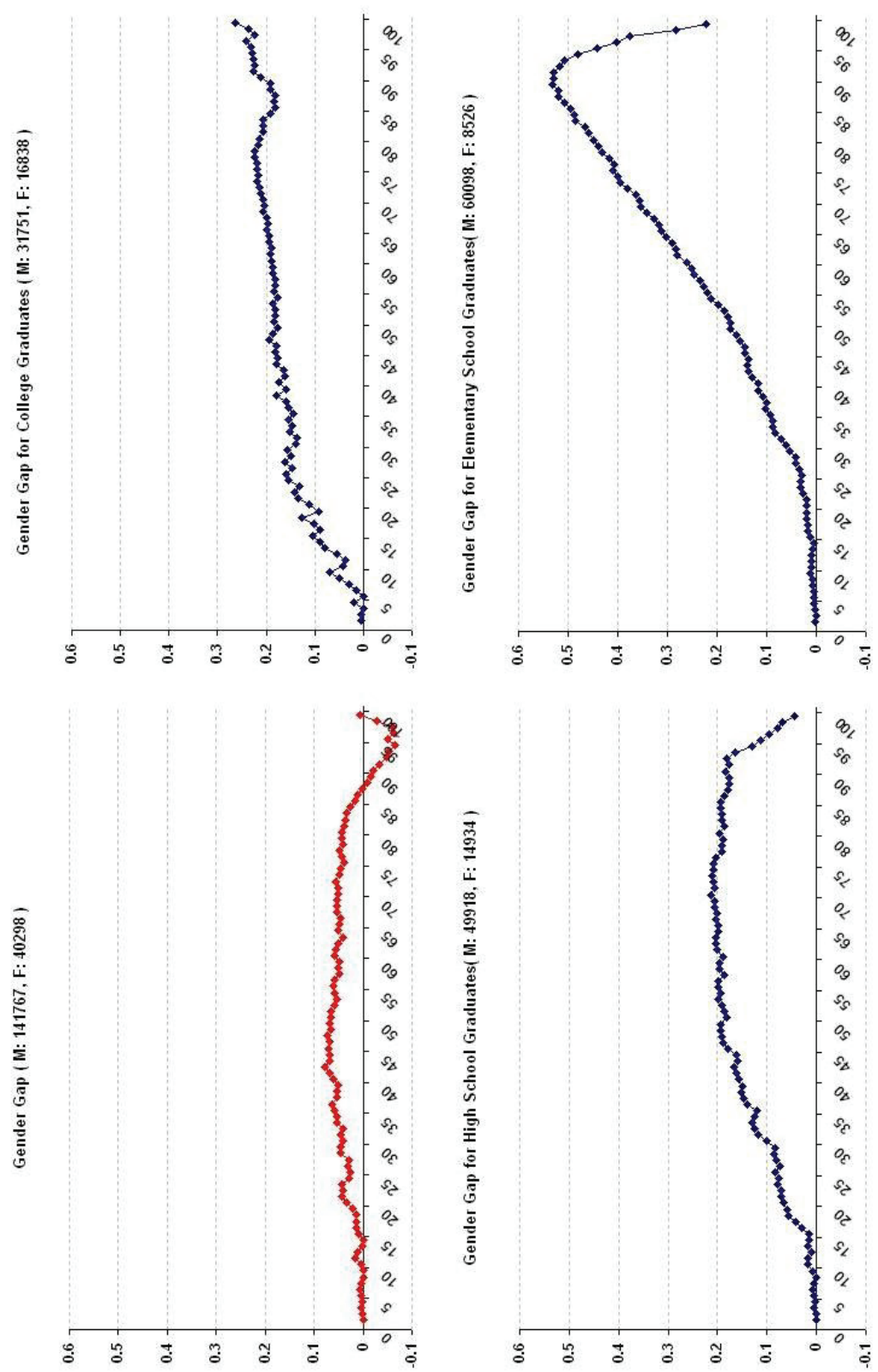

Source: Wage Structure Survey, 2006 


\section{Methodology}

Quantile regression techniques have been used for studying the marginal effects of the covariates on log wages at different quantiles of the wage distribution. Quantile regression techniques are based on estimating the $\mathrm{q}^{\text {th }}$ quantile of log wages, $\ln (w)$, conditional on covariates, $x$. The coefficient vector is the vector that minimizes the sum of absolute errors.

$$
\min \beta(\theta)\left\{\sum_{i: \ln } \theta\left|\ln w_{i}-x_{i} \beta(\theta)\right|+\sum_{i: \ln x_{i} \beta(\theta)}(1-\theta)\left|\ln w_{i}-x_{i} \beta(\theta)\right|\right\}
$$

We start by assuming that the labor market returns do not vary by gender, and analyze how the gender gap in wages change along the distribution when we control for certain labor market characteristics. That is, we run regressions on pooled data, containing both men and women. Then, we let the labor market returns vary by gender and concentrate on the gender differences in returns. To this end, we run quantile regressions separately on male and female samples. Finally, we use an appropriate decomposition technique to measure an upper bound on the part of the gender gap that can be attributed to discrimination.

The decomposition technique used in this paper has been developed by Machado and Mata ${ }^{16}$. The Machado-Mata decomposition is a natural extension to the Blinder-Oaxaca decomposition for quantile regressions. Just like the Blinder-Oaxaca decomposition, it holds exactly in this case since the quantile regression is also linear.

Using the Machado-Mata decomposition, we can generate two counterfactual densities: a female log wage density assuming that women had men's characteristics, but were paid as women $X_{m} \beta_{f}$ $X_{m} \beta_{f}$ and a male log wage density assuming that men had women's characteristics, but were paid as men $X_{f} \beta_{m} X_{f} \beta_{m}$.

$$
\begin{aligned}
& X_{m} \hat{\beta}_{m}(\theta)-X_{f} \hat{\beta}_{f}(\theta)=\left(X_{m}-X_{f}\right) \hat{\beta}_{f}(\theta)+X_{m}\left(\hat{\beta}_{m}(\theta)-\hat{\beta}_{f}(\theta)\right) \\
& X_{m} \hat{\beta}_{m}(\theta)-X_{f} \hat{\beta}_{f}(\theta)=\left(X_{m}-X_{f}\right) \hat{\beta}_{m}(\theta)+X_{f}\left(\hat{\beta}_{m}(\theta)-\hat{\beta}_{f}(\theta)\right)
\end{aligned}
$$

The methodology of the decomposition is as follows. (i) Estimate the coefficients $\beta_{m}$ and $\beta_{f}$ using the male and female data sets, respectively. (ii) At each quantile, randomly draw 1,000 women (with replacement) and use their characteristics to predict wages using the estimated coefficients, i.e. compute $X_{f} \hat{\beta}_{f}$ and $X_{f} \hat{\beta}_{m}$ using the characteristics of randomly drawn 1,000 women at each quantile. (iii) At each quantile, randomly draw 1,000 men (with replacement) and compute $X_{m} \hat{\beta}_{m}$ and $X_{m} \hat{\beta}_{f}$. (iv) Calculate an estimate of the gender wage gap as the difference 16 Ibid. 
between the predicted wages at each quantile using the newly generated wage distribution and the counterfactual distribution.

Let us reiterate. The Machado-Mata decomposition allows us to generate two counterfactual densities: a female log wage density assuming that women had men's characteristics, but were paid as women $X_{m} \hat{\beta}_{f}$ and a male log wage density assuming that men had women's characteristics, but were paid as men $X_{f} \hat{\beta}_{m}$.Then the differences in returns are computed: $X_{m} \hat{\beta}_{m}-X_{m} \hat{\beta}_{f}$ and $X_{f} \hat{\beta}_{m}-X_{f} \hat{\beta}_{f}$.

\section{Results}

\section{I The Gender Wage Gap}

First, we assume that the males and the females have the same returns in the labor market. This allows us to focus on the gender gap when differences in characteristics are controlled for. Technically, running the quantile regressions on the entire sample, we study the coefficient on the female dummy. Table 2 presents the gender gap at the $5^{\text {th }}, 10^{\text {th }}, 25^{\text {th }}, 50^{\text {th }}, 75^{\text {th }}, 90^{\text {th }}$ and $95^{\text {th }}$ percentiles for different specifications. For comparison purposes, we also provide the OLS estimates on the same sample.

The first row marks the raw gender gap at the given percentiles. In the second panel, we report our estimate of the gender wage gap in a regression where we control for basic labor market characteristics: age, age squared, tenure, tenure squared and educational attainment. The gender gap increases in absolute value relative to the observed gender gap. In other words, when we take into account the differences in education levels across genders, we find that the gender gap is actually wider. This finding is in line with the descriptive statistics showing that females in formal employment are better educated. The widening of the gender gap upon controlling for education, starts from the 10th percentile up and becomes more pronounced at and above the median. The gender gap expands from -6.47 percent to -8 percent at the median, from -3.75 percent to -9.21 percent on the $75^{\text {th }}$ percentile. The OLS estimate also expands sizably, from -3 percent to -7.22 percent. Consistent with Figure 2, the gender gap turns negative at the top end of the wage distribution. That is, we find that women earn less than men when we control for education. At the $90^{\text {th }}$ percentile, the gender gap changes sign from 2.21 percent to -6.16 percent, at the $95^{\text {th }}$, from 4.99 percent to -4.48 percent.

The next step is to include arguably endogenous variables, such as industry and occupation of employment. Industrial or occupational segregation may also be considered as labor market discrimination. However, it is still interesting to see how much is left when all other relevant labor market characteristics are taken into account. When we include industry dummies in the regressions, we can explain a non-trivial part of the gender gap at and above the median. It shrinks 
by almost half at the median from 8 percent to 4.98 percent and at the $75^{\text {th }}$ percentile from -9.21 to -5.18 . The decreases in the upper part are similar but smaller in size. The gender gap shrinks from -4.48 to -3.70 at the $95^{\text {th }}$ percentile. When occupations are included in the regressions, the gender gap continues to narrow. Note that at the upper end of the wage distribution, the gender gap seems almost stable around 3.90 percent.

We control for firm size in the next panel of Table 2. It is interesting to see that firm size explains the gender gap above the median although it widens the gender gap below the median. At the $10^{\text {th }}$ percentile, the gender gap widens from 1.04 to 1.30 percent. At the $90^{\text {th }}$ percentile, including firm size in regressions causes the gender gap to shrink from 3.87 to 2.80 percent.

In the last panel, we include controls for administrative posts and collective bargaining coverage. Doing so helps explain the gender wage gap at all quantiles of the wage distribution. At and above the median, the gender gap seems pretty stable at 3 percent.

At this point, it is interesting to compare the first and the last panel of Table 2. Under the assumption that men and women have the same returns in the labor market, a gender wage gap remains when we control for various labor market characteristics. Including the control variables reduces the gender wage gap at the median, but widens it considerably at the very high end of the distribution. The raw gender gap points to a 4.99 percent higher wages for females whereas the gender gap with all controls points to a 3.11 percent higher wages for males at the $95^{\text {th }}$ percentile. The differences in male and female characteristics hide the magnitude of gender wage gap.

Now we will concentrate on the gender differences in returns to labor market characteristics. Table 3 provides the quantile regressions by gender to study the gender differences in returns to basic labor market characteristics.

The returns to age are higher for females than for males in the labor market. Remember that age is a proxy for labor market experience, and that women in our sample are younger than men. More importantly, the gender differences in returns to age increase as we move up the wage distribution. At the seventy-fifth percentile, female wages increase by almost 6 percent with one year of age, whereas male wages increase by about 3 percent. Note that women in the sample are younger and thus may have higher returns. On the other hand, males seem to enjoy higher returns to tenure than females do.

Note that returns to education paint a different picture. Returns to a high school degree are higher for a female than for a male. Moreover, the gender differences in returns to a high school degree increase as we move up the wage distribution. At the twenty-fifth percentile, the returns to a high school degree is 6.44 percent for a female vs. 4.46 percent for a male, i.e. the gender gap in returns to a high school degree is $1.98^{17}$. We observe that the gender gap in returns to high school increases monotonically along the distribution.

17 At the twenty-fifth percentile, the returns to a high school degree is 6.44 percent for a female vs. 4.46 percent for a male, i.e. the gender gap in returns to a high school degree is 1.98 
Table 2: Estimates of the gender wage gap using pooled data

\begin{tabular}{|c|c|c|c|c|c|c|c|c|}
\hline & $5^{\text {th }}$ & $10^{\text {th }}$ & $25^{\text {th }}$ & $50^{\text {th }}$ & $75^{\text {th }}$ & $90^{\text {th }}$ & $95^{\text {th }}$ & OLS \\
\hline \multirow{2}{*}{ Observed } & $-0.0037^{* * *}$ & $-0.005^{* * *}$ & $-0.0257^{* * *}$ & $-0.0647^{* * *}$ & $-0.0375^{* * *}$ & $0.0221^{* * *}$ & $0.0499^{* * *}$ & $-0.03^{* * *}$ \\
\hline & -0.0002 & 0 & -0.0039 & -0.0052 & -0.0069 & -0.008 & -0.0115 & -0.0035 \\
\hline \multirow[t]{2}{*}{ Basic Controls } & $-0.0038^{* * *}$ & $-0.0111^{* * *}$ & $-0.0411^{\star * *}$ & $-0.08^{* * *}$ & $-0.0921^{* * *}$ & $-0.0616^{* * *}$ & $-0.0448^{* * *}$ & $-0.0722^{\star * *}$ \\
\hline & -0.0003 & -0.0005 & -0.0018 & -0.0028 & -0.0038 & -0.0056 & -0.0071 & -0.0029 \\
\hline \multirow[t]{2}{*}{ Industry } & $-0.0041^{* * *}$ & $-0.0128^{* * *}$ & $-0.0344^{* * *}$ & $-0.0498^{* * *}$ & $-0.0518^{* * *}$ & $-0.0372^{\star * *}$ & $-0.037^{* * *}$ & $-0.0548^{* * *}$ \\
\hline & -0.0004 & -0.0008 & -0.0018 & -0.0028 & -0.0036 & -0.0055 & -0.0068 & -0.0029 \\
\hline \multirow[t]{2}{*}{ Occupation } & $-0.0041^{* * *}$ & $-0.0104^{* * *}$ & $-0.0277^{* * *}$ & $-0.0434^{* * *}$ & $-0.0388^{* * *}$ & $-0.0387^{* * *}$ & $-0.0398^{* * *}$ & $-0.0416^{* * *}$ \\
\hline & -0.0005 & -0.0008 & -0.0018 & -0.0026 & -0.0038 & -0.0051 & -0.007 & -0.0028 \\
\hline \multirow[t]{2}{*}{ Firm Size } & $-0.0063^{* * *}$ & $-0.013^{* * *}$ & $-0.0282^{* * *}$ & $-0.0353^{* * *}$ & $-0.0339^{* * *}$ & $-0.028^{* * *}$ & $-0.0363^{* * *}$ & $-0.0312^{* * *}$ \\
\hline & -0.0009 & -0.0015 & -0.0019 & -0.0026 & -0.0035 & -0.0051 & -0.0068 & -0.0028 \\
\hline \multirow[t]{2}{*}{ Admin. Post and Coll. Barg. } & $-0.0047^{* * *}$ & $-0.0107^{* * *}$ & $-0.0221^{* * *}$ & $-0.0313^{* * *}$ & $-0.0295^{* * *}$ & $-0.0209^{* * *}$ & $-0.0311^{* * *}$ & $-0.0259^{* * *}$ \\
\hline & -0.0009 & -0.0014 & -0.0017 & -0.0025 & -0.0035 & -0.0053 & -0.0066 & -0.0027 \\
\hline
\end{tabular}

A different pattern is observed for vocational high school and college degrees. Males have higher returns at the lower end of the distribution, whereas females have higher returns at the higher end. For example, at the twenty-fifth percentile, a male with a vocational high school degree earns 5 percent more than a male without a high school degree. At the same percentile, the returns to a vocational degree is 2.6 percent for a female. Returns to a college degree at the same percentile is 11.2 percent for males and only 7.3 percent for females. As we move up the distribution, women have consistently higher returns. At the seventy-fifth percentile, women have higher returns than men and the differences are getting larger. The returns to a vocational degree is 48 percent for females and 36 percent for males. Note that college premium is very high. The OLS result indicate that the returns to college are about 73.5 percent on average. The quantile regression results indicate returns of more than 100 percent at the upper half of the wage distribution. At this level, the gender gap in returns to a college degree is comparatively smaller at the top of the distribution.

The quantile regressions by gender indicate clearly that the returns to labor market characteristics differ for males and females. We observe that females enjoy returns to certain labor market characteristics, such as age and education. Recall that controlling for differences in characteristics, we revealed a larger gender wage gap than what was observed in the data. It is now time to decompose the gender gap into two parts, one stemming from differences in characteristics, the other from differences in returns to quantify the discrimination in the labor market. 
Table 3: Quintile regressions by gender

\begin{tabular}{|c|c|c|c|c|c|c|c|c|}
\hline & $5^{\text {th }}$ & $10^{\text {th }}$ & $25^{\text {th }}$ & $50^{\text {th }}$ & $75^{\text {th }}$ & $90^{\text {th }}$ & $95^{\text {th }}$ & OLS \\
\hline \multicolumn{9}{|c|}{ FEMALE $(n=40,298)$} \\
\hline \multirow[t]{2}{*}{ Age } & $0.0031^{* * *}$ & $0.0048^{* * *}$ & $0.0137^{* * *}$ & $0.0344^{* * *}$ & $0.0591^{* * *}$ & $0.0768^{* * *}$ & $0.0963^{* * *}$ & $0.0589^{* * *}$ \\
\hline & -0.0002 & -0.0003 & -0.0009 & -0.0021 & -0.0035 & -0.0045 & -0.0069 & -0.0022 \\
\hline \multirow[t]{2}{*}{ Age2 } & $-0.0000^{* * *}$ & $-0.0000^{* * *}$ & $-0.0002^{\star * *}$ & $-0.0004^{* * *}$ & $-0.0007^{\star * *}$ & $-0.0007^{\star * *}$ & $-0.0009^{* * *}$ & $-0.0007^{\star * *}$ \\
\hline & 0 & 0 & 0 & 0 & 0 & 0 & -0.0001 & 0 \\
\hline \multirow[t]{2}{*}{ Tenure } & $-0.0051^{* * *}$ & $-0.0040^{* * *}$ & $0.0209^{* * *}$ & $0.0534^{* * *}$ & $0.0625^{* * *}$ & $0.0553^{* * *}$ & $0.0508^{* * *}$ & $0.0465^{\star * *}$ \\
\hline & -0.0002 & -0.0003 & -0.0007 & -0.0014 & -0.0021 & -0.0026 & -0.004 & -0.0014 \\
\hline \multirow[t]{2}{*}{ Tenure2 } & $0.0906^{* * *}$ & $0.1335^{\star * *}$ & $0.0704^{* * *}$ & $-0.0728^{* * *}$ & $-0.1345^{\star * *}$ & $-0.1415^{\star * *}$ & $-0.1332^{* * *}$ & $-0.0777^{* * *}$ \\
\hline & -0.001 & -0.0014 & -0.0034 & -0.0066 & -0.0104 & -0.013 & -0.0202 & -0.0067 \\
\hline \multirow[t]{2}{*}{ HS } & $0.0087^{* * *}$ & $0.0156^{* * *}$ & $0.0644^{* * *}$ & $0.1873^{\star * *}$ & $0.3433^{\star * *}$ & $0.4433^{* * *}$ & $0.4724^{* * *}$ & $0.2882^{* * *}$ \\
\hline & -0.0009 & -0.0012 & -0.0033 & -0.0073 & -0.0117 & -0.0147 & -0.0215 & -0.0075 \\
\hline \multirow[t]{2}{*}{ Voc HS } & $0.0140^{* * *}$ & $0.0262^{* * *}$ & $0.0900^{* * *}$ & $0.2736^{\star * *}$ & $0.4273^{\star * *}$ & $0.4842^{* * *}$ & $0.5062^{* * *}$ & $0.3536^{* * *}$ \\
\hline & -0.0012 & -0.0016 & -0.0044 & -0.0098 & -0.0156 & -0.0194 & -0.0283 & -0.01 \\
\hline \multirow[t]{2}{*}{ College } & $0.0309^{* * *}$ & $0.0728^{* * *}$ & $0.3282^{* * *}$ & $0.6772^{* * *}$ & $0.9475^{\star * *}$ & $1.1560^{* * *}$ & $1.1869^{* * *}$ & $0.7351^{* * *}$ \\
\hline & -0.0008 & -0.0011 & -0.003 & -0.0067 & -0.0107 & -0.0133 & -0.0194 & -0.0068 \\
\hline \multirow[t]{2}{*}{ Constant } & $6.2243^{\star * *}$ & $6.1946^{\star * *}$ & $6.0065^{\star * *}$ & $5.6440^{* * *}$ & $5.3117^{\star * *}$ & $5.1668^{\star * *}$ & $4.9688^{* * *}$ & $5.1849^{* * *}$ \\
\hline & -0.0041 & -0.0053 & -0.0149 & -0.0349 & -0.0593 & -0.0778 & -0.1187 & -0.0357 \\
\hline \multicolumn{9}{|c|}{$\operatorname{MALE}(\mathrm{n}=141,767)$} \\
\hline \multirow[t]{2}{*}{ Age } & $0.0014^{* * *}$ & $0.0028^{\star * *}$ & $0.0076^{* * *}$ & $0.0163^{\star * *}$ & $0.0339^{\star * *}$ & $0.0496^{* * *}$ & $0.0544^{* * *}$ & $0.0314^{* * *}$ \\
\hline & -0.0001 & -0.0002 & -0.0005 & -0.001 & -0.0014 & -0.0021 & -0.0026 & -0.001 \\
\hline \multirow[t]{2}{*}{ Age2 } & $-0.0000^{* * *}$ & $-0.0000^{* * *}$ & $-0.000^{\star * *}$ & $-0.0001^{\star * *}$ & $-0.0003^{\star * *}$ & $-0.000^{* * *}$ & $-0.0004^{* * *}$ & $-0.0003^{\star * *}$ \\
\hline & 0 & 0 & 0 & 0 & 0 & 0 & 0 & 0 \\
\hline \multirow[t]{2}{*}{ Tenure } & $-0.0050^{\star * *}$ & $0.0003^{* * *}$ & $0.0349^{* * *}$ & $0.0685^{\star * *}$ & $0.0713^{\star * *}$ & $0.0611^{* * *}$ & $0.0524^{* * *}$ & $0.0531^{* * *}$ \\
\hline & 0 & -0.0001 & $(0.0004)$ & -0.0006 & -0.0009 & -0.0013 & -0.0016 & -0.0006 \\
\hline \multirow[t]{2}{*}{ Tenure2 } & $0.1060^{\star * *}$ & $0.1230^{\star * *}$ & $0.0249^{* * *}$ & $-0.1090^{* * *}$ & $-0.1476^{\star * *}$ & $-0.1427^{* * *}$ & $-0.1349^{* * *}$ & $-0.0831^{\star * *}$ \\
\hline & $(0.0004)$ & -0.0007 & -0.0017 & -0.0027 & -0.0038 & -0.0056 & -0.0074 & -0.0027 \\
\hline \multirow[t]{2}{*}{ HS } & $0.0045^{\star * *}$ & $0.0114^{* * *}$ & $0.0446^{* * *}$ & $0.1210^{* * *}$ & $0.1862^{* * *}$ & $0.2373^{\star * *}$ & $0.2831^{\star * *}$ & $0.1622^{* * *}$ \\
\hline & -0.0003 & -0.0006 & -0.0018 & -0.0034 & -0.0048 & -0.0067 & -0.0085 & -0.0034 \\
\hline \multirow[t]{2}{*}{ Voc HS } & $0.0182^{\star * *}$ & $0.0495^{\star * *}$ & $0.1990^{\star * *}$ & $0.3222^{\star * *}$ & $0.3344^{\star * *}$ & $0.3646^{\star * *}$ & $0.4175^{* * *}$ & $0.3135^{* * *}$ \\
\hline & -0.0004 & -0.0007 & -0.0021 & -0.004 & -0.0057 & -0.008 & -0.0101 & -0.004 \\
\hline \multirow[t]{2}{*}{ College } & $0.0340^{* * *}$ & $0.1172^{\star * *}$ & $0.3798^{\star * *}$ & $0.6751^{\star * *}$ & $0.9404^{\star * *}$ & $1.1272^{\star * \star}$ & $1.1997^{\star * *}$ & $0.7055^{\star * *}$ \\
\hline & -0.0003 & -0.0005 & -0.0017 & -0.0033 & -0.0047 & -0.0066 & -0.0082 & -0.0033 \\
\hline \multirow[t]{2}{*}{ Constant } & $6.2537^{\star * *}$ & $6.2250^{* * *}$ & $6.1105^{\star * *}$ & $5.9760^{\star * *}$ & $5.8045^{\star * *}$ & $5.7404^{* * *}$ & $5.7872^{* * *}$ & $5.7378^{* * *}$ \\
\hline & -0.0018 & -0.0031 & -0.0094 & -0.0183 & -0.0262 & -0.0374 & -0.048 & -0.0182 \\
\hline
\end{tabular}




\subsection{Decomposition Results}

Fligure 3 shows the gender gap at each quantile for various counterfactuals constructed using male returns to female characteristics. It answers the following question: If males had female characteristics but were rewarded as if they were males, what would the gender gap have been? The simple answer to that question is, the gender gap would have been wider than what we observe. Controlling for basic characteristics, such as education, age and tenure, widens the gender gap considerably, especially at the top half of the distribution. At the median, the gender gap increases from 6.47 percent to 8.99 percent; at the $75^{\text {th }}$ quantile, from 3.75 percent to 9.92 percent.

Observe again that the gender wage gap calculated at each percentile reveals a positive gap for the upper part of the wage distribution. In other words, raw data indicates that females have higher wages at the highest decile of the wage distribution. One of the most interesting results of the decomposition refers to this part of the distribution. When we construct a counterfactual wage distribution where female characteristics are being rewarded by male returns, we observe that the gender wage gap becomes negative at the top decile of the wage distribution as well. The gender wage gap at the ninetieth percentile changes from 4.99 percent to -4.76 percent, using only basic controls. In absolute value, this refers to a change of 10 percent.

Controlling for potentially endogenous characteristics such as industry, occupation and firm size, we can explain some part of the gender gap, especially between the $25^{\text {th }}$ and $75^{\text {th }}$ quantiles. The unexplained part of the gender gap shrinks from 7.8 percent to 4.83 percent on the $25^{\text {th }}$, and from 9.92 percent to 3.22 percent on the $75^{\text {th }}$ quantile. Note that this is a very conservative estimate of the unexplained part of the gender gap as these variables fail to contribute to explaining the gender gap if women are selected into industries, occupations and firms.

Table 4: Machado-Mata decomposition results: Differences in returns

\begin{tabular}{|c|c|c|c|c|c|c|c|}
\hline & $5^{\text {th }}$ & $10^{\text {th }}$ & $25^{\text {th }}$ & $50^{\text {th }}$ & $75^{\text {th }}$ & $90^{\text {th }}$ & $95^{\text {th }}$ \\
\hline Observed & -0.0037 & -0.005 & -0.0257 & -0.0647 & -0.0375 & 0.0221 & 0.0499 \\
\hline \multicolumn{8}{|c|}{$X_{f} \hat{\beta}_{m}-X_{f} \hat{\beta}_{f}$} \\
\hline Basic controls & -0.0094 & -0.0339 & -0.074 & -0.0899 & -0.0992 & -0.0668 & -0.0476 \\
\hline $\mathrm{BC}$, Industry & -0.0094 & -0.0307 & -0.0627 & -0.0722 & -0.0684 & -0.0453 & -0.0451 \\
\hline BC, Ind., Occupation & -0.0091 & -0.0219 & -0.0489 & -0.0523 & -0.0439 & -0.0264 & -0.0433 \\
\hline BC, Ind., Occ., Firm S. & -0.0096 & -0.0214 & -0.043 & -0.0447 & -0.0341 & -0.0131 & -0.0339 \\
\hline All controls & -0.0086 & -0.0157 & -0.035 & -0.037 & -0.0322 & -0.0101 & -0.035 \\
\hline \multicolumn{8}{|c|}{$X_{m} \hat{\boldsymbol{\beta}}_{m}-X_{m} \hat{\boldsymbol{\beta}}_{f}$} \\
\hline Basic controls & -0.0145 & -0.0299 & -0.078 & -0.108 & -0.124 & -0.0795 & -0.0512 \\
\hline $\mathrm{BC}$, Industry & -0.0171 & -0.0289 & -0.0713 & -0.0918 & -0.0789 & -0.0539 & -0.0265 \\
\hline BC, Ind., Occupation & -0.0138 & -0.0253 & -0.0602 & -0.0767 & -0.0669 & -0.0545 & -0.0515 \\
\hline BC, Ind., Occ., Firm S. & -0.0177 & -0.029 & -0.0582 & -0.0609 & -0.0443 & -0.0353 & -0.0377 \\
\hline All controls & -0.0212 & -0.0323 & -0.0483 & -0.0597 & -0.0495 & -0.0281 & -0.0422 \\
\hline
\end{tabular}


Figure 3: Machado-Mata decomposition: $X_{f} \hat{\beta}_{m}-X_{f} \hat{\beta}_{f}$

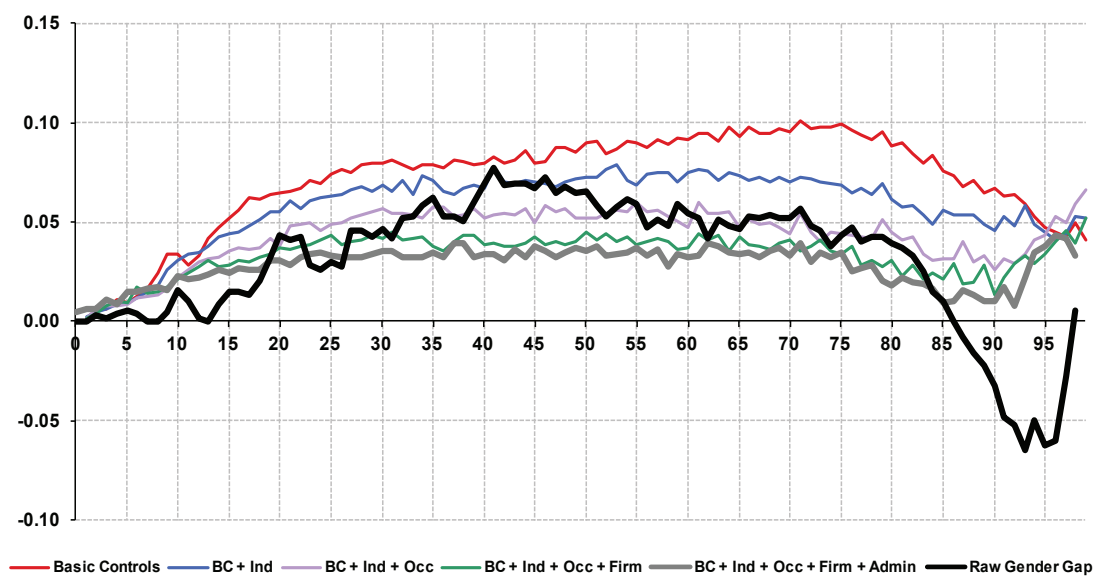

Figure 4: Machado-Mata decomposition: $X_{m} \hat{\beta}_{m}-X_{m} \hat{\beta}_{f}$

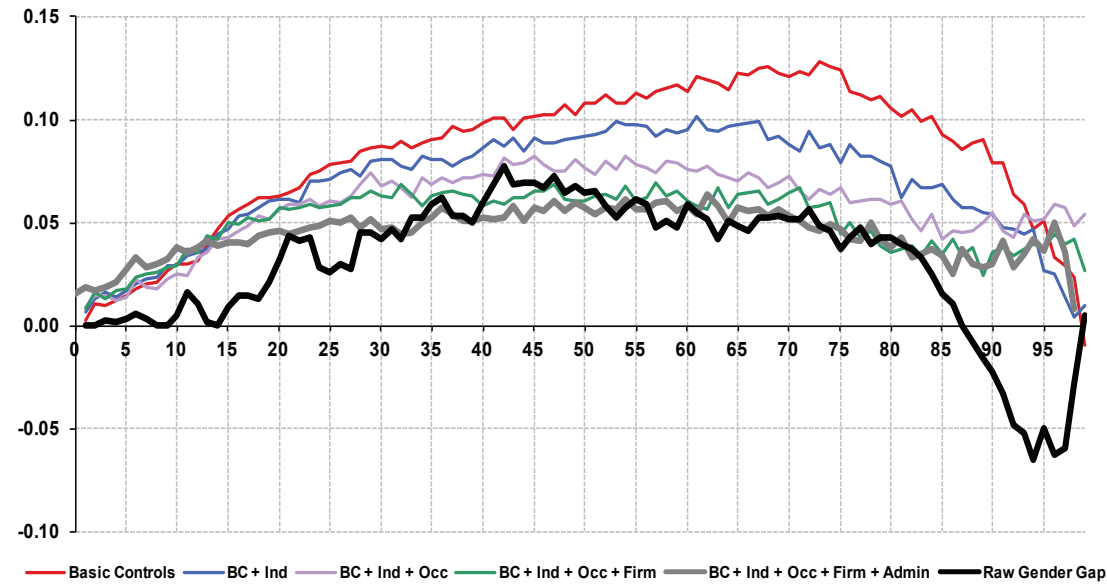

The reciprocal exercise provides results that move in similar directions. The question for Fligure 4 is as follows: If females had male characteristics but were rewarded as females, what would the gender gap have been? Once again, the gender gap would have been wider. Controlling for basic characteristics widens the gender gap, however, adding controls for various firm-level characteristics explain smaller parts of the gender gap. When all controls are included, the gender gap does not seem to be much smaller than the observed gender gap. Moreover, it becomes considerably wider at the lower and at the upper part of the distribution. 
To sum up, the decomposition results reveal that the gender gap in wages stem from differences in returns to labor market characteristics. If we assume that males had female characteristics, controlling for basic characteristics actually widens the gender gap, but including firmlevel controls help explain some of it. On the other hand, if we assume that females had male characteristics, we find that the gender gap becomes much wider, and even when we include all controls, we fail to explain the gender gap.

\section{Conclusion}

In this paper, we study the gender wage gap along the wage distribution in Turkey, using a firm level data set. Two striking patterns emerge when analyzing raw data. The gender gap seems to be very close to zero at the lower end of the distribution. Moreover, at the higher end of the distribution, it looks as if men earn less than women. Following the literature, we conduct quantile regressions to shed light on the gender gap along the entire wage distribution. We start by assuming that the returns are the same across genders, and concentrate on the gender wage gap controlling for differences in characteristics. We find that controlling for education widens the gender gap considerably. When education, potential labor market experience and tenure are taken into account, women earn about 8 percent less than men at the median. At the higher end of the wage distribution, women earn 4.5 percent less than men, contrary to what the raw data suggests. Adding arguably endogenous variables such as industry, occupation and firm-level variables reduce the gender wage gap. The largest reduction happens around the median. On the other hand, we find that there is a sizeable gender gap that cannot be accounted for by differences in characteristics at the upper end of the wage distribution.

Then, we focus on differences in returns, estimating separate quantile regressions for males and females. We find that the returns to labor market characteristics are different for males and females. Moreover, the gender gaps in returns, especially in education, deepen as we move up the wage distribution.

Differences in characteristics and in returns indicate that we should decompose the gender wage gap into a part stemming from differences in characteristics and a part from differences in returns. We try to answer the following question: If males had female characteristics, what would the gender gap have been? Controlling for education, we find that the gender gap is actually much larger than what the raw data indicates. Including other controls, we can explain about half of the gender gap around the median, and even less at other parts of the distribution. The analogous question for males tries to document the counterfactual gender gap constructed from male characteristics being rewarded by female returns. This counterfactual gender gap is even larger. Controlling for education widens the gender gap and including other controls can only reduce it to the observed gender gap at best. In other words, the decomposition exercises indicate that the gender wage gap originates in large part from differences in returns. 


\section{References}

ALBRECHT, James and Bjorklund, Anders and Vroman, Susan, "Is There a Glass Ceiling in Sweden?", Journal of Labor Economics, 21 (1), 2003, 145-77.

ALBRECHT, James and van Vuuren, Aico and Vroman, Susan, "Counterfactual Distributions with Sample Selection Adjustments: Econometric Theory and an Application to the Netherlands", Labour Economics, 16(4), 383-396.

AMUEDO-DORANTES, Catalina and De la Rica, Sara “The Impact Of Gender Segregation on MaleFemale Wage Differentials: Evidence from Matched Employer-Employee Data for Spain”, IZA Discussion Papers 1742, Institute for the Study of Labor (IZA), 2005.

ANTONCZYK, Dirk and Fitzenberger, Bernd and Sommerfeld, Katrin, "Rising Wage İnequality, the Decline of Collective Bargaining, and the Gender Wage Gap”, Labour Economics, 17(5), 835847, 2010, April

ANTÓN, José-Ignacio and Muñoz de Bustillo, Rafael and Carrera, Miguel, "Labor Market Performance of Latin American and Caribbean Immigrants in Spain", Journal of Applied Economics, Vol. 13, No. 2, pp. 233-261, November 2010.

ARULAMPALAM, Wiji and L. Booth, Alison and Bryan, Mark L. "Is There a Glass Ceiling over Europe? Exploring the Gender Pay Gap across the Wage Distribution" Industrial and Labor Relations Review, 60(2), 163-186, October 2004.

BAYARD, Kimberly and Hellerstein, Judith and Neumark,David and Troske,Kenneth, "New Evidence on Sex Segregation and Sex Differences in Wages from Matched Employee-Employer Data", Journal of Labor Economics, University of Chicago Press,vol.21(4), 887-922, October 2003.

BLINDER, Alan, "Wage Discrimination: Reduced Form and Structural Estimates", Journal of Human Resources, 8 (4), 436-455,1973.

CHRISTOFIDES, Louis N., and Polycarpou, Alexandros, and Vrachimis, Konstantinos, "Gender Wage Gaps, 'Sticky Floors' and 'Glass Ceilings' in Europe”, Labour Economics, 21, 86-102, 2013.

CUDEVILLE, Elisabeth and Gurbuzer, Leman Yonca, "Gender Wage Discrimination in the Turkish Labor Market: Can Turkey Be Part of Europe?”, Comparative Economic Studies, 52(3), 429-463, September 2010.

DAYIOĞLU, Meltem, and Tunalı, Insan, "Falling behind While Catching up: Changes in the FemaleMale Wage Differential in Urban Turkey 1988 to 1994", Unpublished manuscript, 2003.

DAYIOĞLU, Meltem. and Kasnakoğlu, Zehra, “Kentsel Kesimde Kadın ve Erkeklerin Işgücüne Katılımları ve Kazanç Farklılıkları”, Metu Studies in Development 24(3), 329-361, 1997.

GROSHEN, Erica L, “The Structure of the Female/Male Wage Differential: Is it Who You are, What You Do, or Where You Work?”, Journal of Human Resources, 26(3), 457-472, 1991.

GUNDUZ-HOSGOR, Ayşe and Smits, Jeroen, "Variation in Labor Market Participation of Married Women in Turkey”, Women's Studies International Forum, 31(2), 104-117. (2008).

ILKKARACAN, İpek and Selim, Raziye, “The Gender Wage Gap in the Turkish Labor Market”, Review of Labour Economics and Industrial Relations, 21(2), 563-59, 2007.

JELLAL, Mohamed and Nordman, Christophe and Wolff, F. Charles, "Evidence on the Glass Ceiling Effect in France Using Matched Worker-Firm Data”, Applied Economics, 40(24), 3233-3250, 2008.

KARA, Orhan, "Occupational Gender Wage Discrimination in Turkey". Journal of Economic Studies, 33(2), 130-143, 2006.

KUNZE, Astrid. (2000). “The Determination of Wages and the Gender Wage Gap: A Survey”, IZA Discussion Papers 193, Institute for the Study of Labor (IZA), August 2000. 
LE, Anh and Miller, Paul, "Glass Ceiling and Double Disadvantage Effects: Women in the US Labour Market”, Applied Economics, 42(5), 603-613, 2010.

MACHADO, José A. F. and Mata, José, “Counterfactual Decomposition of Changes in Wage Distributions using Quantile Regression”, Journal of Applied Econometrics, 20(4), 445-465, 2005.

OAXACA, Ronald, "Male-Female Wage Differentials in Urban Labor Markets”. International Economic Review, 14(3), 693-709, 1973.

ÖZCAN, Y. Ziya and Metin-Özcan, Kıvılcım and Ücdoğruk, Şenay, "Wage Differences by Gender, Wage and Self Employment in Urban Turkey: The Case of Istanbul”, Journal of Economic Cooperation, 24(1), 1-24. (2003).

RICA, Sara de la, J. Dolado, Juan and Llorens, "Ceilings or Floors? Gender Wage Gaps by Education in Spain”, Journal of Population Economics, 21(3), 751-776. July 2008.

TANSEL, Aysit, "Self-Employment Wage Employment Choice and Returns to Education for Urban Men and Women in Turkey" Economic Research Forum Working Papers 9804, 1998.

TANSEL, Aysit, "Wage Earners, Self Employed and Gender in the Informal Sector in Turkey” Economic Research Forum Working Papers 0102, 2003.

TANSEL, Aysit, "Public-Private Employment Choice, Wage Differentials and Gender in Turkey", IZA Discussion Papers 1262, Institute for the Study of Labor (IZA), August 2004.

TANSEL, Aysit, "Public-Private Employment Choice, Wage Differentials and Gender in Turkey", Economic Development and Cultural Change, 53(2), 453-77, 2005.

TANSEL, Aysit, and Fatma Bircan Bodur, "Wage inequality and returns to education in Turkey: A quantile regression analysis", Review of Development Economics 16.1 (2012): 107-121. 
